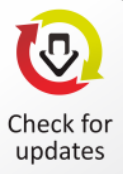

updates
Article Type: Research Paper

\section{Corporate Governance, Environmental Responsibility and Firm Value: An Empirical Study in Indonesia and Malaysia}

\author{
Rintan Nuzul Ainy ${ }^{1 *}$ and Zuni Barokah ${ }^{2}$
}

ABSTRACT: This study examines the correlation between corporate governance, environmental responsibility, and firm value in Indonesia and Malaysia. This study extends the literature in consideration of the role of environmental responsibility in indirect correlation between corporate governance and firm value. The environmental responsibility data index is calculated by conducting a content analysis of companies' annual and sustainability reports in 2013. The other data are obtained from the database of OSIRIS, Bursa Malaysia (Stock Exchange of Malaysia), and Bursa Efek Indonesia (Indonesia Stock Exchange). The results show that corporate governance influences the company's decision in performing voluntary activities such as environmental responsibility. This study shows that Malaysian and Indonesian markets do not respond to environmental responsibility information. It may be considered that the public in Malaysia and Indonesia lacks awareness of the importance of environmental responsibility.

KEYWORDS: Corporate Governance; Environmental Responsibility; Firm Value

\section{Introduction}

Ainy, R., N., \& Barokah, Z. (2019). Corporate Governance, Environmental Responsibility and Firm Value: An Empirical Study in Indonesia and Malaysia. Journal of Accounting and Investment, 20(2), 59-75.

\section{ARTICLE HISTORY \\ Received:}

7 August 2018

Reviewed:

22 September 2018

Revised:

7 December 2018

Accepted:

13 April 2019
Profit (financial performance) is currently not the only aspect a company should pay attention to. There is social and environmental responsibility a company must fulfill in order to continue its operation and obtain society's support. This statement is supported by Jo and Harjoto (2012), that the purpose a company performs social and environmental responsibility activities is not only to gain profit, but also because of ethic reasons and in fulfillment of their social obligations.

Social and environmental responsibility activities are still low and voluntary, particularly in developing countries. An increase of investment in developing countries (US SIF, 2012) causes increasing environmental exploitation in those countries. This is the background of the researcher's assumption that environmental responsibility issues in developing countries are higher than in any other countries. This research takes Indonesian and Malaysian companies as its samples since both countries 
have the highest pollution level in Southeast Asia in 2013 (http://data.worldbank.org/). Corporate governance and firm value are one antecedent factor and implication a company takes into consideration when it decides to perform environmental responsibility (Al-Tuwaijri, Christensen, \& Hughes, 2004; Alsaeed, 2006; Gamerschlag, Möller, \& Verbeeten, 2010; Jo \& Harjoto, 2011). Spitzeck (2009) states that the corporate governance system requires a manager not only to pay attention to shareholders' interest but also that of stakeholders in general (stakeholder theory). The legitimacy theory also states that a company cannot be separated from social context; a company has a social contract with its surrounding environment (Holder-webb, Cohen, Nath, \& Wood, 2009). A company will improve its environmental responsibility if it is supported by a good governance system.

Based on the stakeholder theory, a company is not only responsible economically (to shareholders), but also non-economically to other concerned parties. Corporate survivability depends on the support given by all stakeholders; depends on how the company manages its relationship with customers, employees, suppliers, society, community, investors, etc. (Freeman \& Phillips, 2002). A company which performs environmental responsibility is deemed to be fulfilling such non-economic obligation, which thus leads to increasing firm value, a determinant of corporate survivability.

The correlation pattern of corporate governance, environmental responsibility, and firm value is unclear in developing countries. Previous research (Jo \& Harjoto, 2012) tests the correlation in the US and finds that there is an indirect correlation between corporate governance and firm value, which is social and environmental responsibility serving as mediator. This research differs from previous research (Jo \& Harjoto, 2012) in some ways. Jo and Harjoto (2012) test the correlation in developed countries context (US), while this research desires to fill the research gap by testing the correlation pattern of governance, environmental responsibility, and firm value in developing countries (Indonesia and Malaysia). According to Tsamenyi et al. (2007), different characteristics between developing and developed countries may cause a difference in different governance correlation models. The previous research obtains CSR measurement from the database of Kinder, Lydenberg, and Domini's (KLD's) Stats, while this research develops environmental responsibility activity disclosure index through content analysis based on GRI G4 guideline. This research is going to test the correlation between corporate governance, environmental responsibility, and firm value in developing countries simultaneously. Social and environmental responsibility is deemed an agency conflict resolution set which may increase firm value.

This research contributes to social responsibility literature, particularly in the environmental aspect, in developing countries. This research tests how corporate governance and environmental responsibility simultaneously influence firm value. This research tests the correlation between corporate governance and environmental responsibility in Indonesia and Malaysia because, in the globalization era, Indonesia and Malaysia start to attract investment opportunity which will affect their environment in the long run. This research also tests how corporate governance and environmental responsibility influence Indonesian and Malaysian non-tested companies' performance. 


\section{Literature Review and Hypotheses Development}

\section{Agency Theory}

The agency theory explains the relationship of two parties, principal as employer and agent as an employee. Principal as shareholder delegates the decision making authority on their behalf tot he agent (manager) (Jensen \& Meckling, 1976). The issue arising from this principal-agent relationship is a conflict of interest, in which the agent does not always decide on the principal's interest. This theory also reflects information asymmetry between the manager as the agent and shareholder as the principal. Information asymmetry arises when the agent (manager) has more information than the principal and the other stakeholders. This information asymmetry will decline if the agent discloses the information. Corporate governance is considered to be able to oversee and control the agent so as not to perform moral hazard behavior and to make the disclosure. Declining information asymmetry will increase firm value.

\section{Stakeholder Theory}

This theory states that a company is not an entity which operates only for its own interest, but it should provide the stakeholder's benefits. A company is not only responsible economically (to shareholders), but also non-economically to other concerned parties. Corporate survivability depends on the support given by all stakeholders; depends on how the company manages its relationship with customers, employees, suppliers, society, community, investors, etc. (Freeman \& Phillips, 2002). A good corporate governance system supports all stakeholders' interest, one of which is the fulfillment of the need for environmental responsibility information made by a company. Upon fulfillment of the interest, the relationship between company and stakeholders will get better, in which it gains support, which will increase its firm value.

\section{Legitimacy Theory}

The legitimacy theory states that an organization should not only pay attention to investors' interest but should also to the public interest in general (Deegan \& Rankin, 1997). The basis of legitimacy theory is the existence of a social contract between a company and the society where the company is located and uses its resources. The concept of social contract is that all social institutions, including companies, operate among the society through social contract, either explicitly or implicitly, in which their growth continuity is based on outcome which may socially be given to wide community and the economic, social or political benefits may be distributed to groups pursuant to their capacity. Any environmental activity disclosure made by a company is a form of its corporate responsibility for the utilization of existing resources. The social contract responsibility may be fulfilled with the support of a good governance system, which will then affect firm value. 
Ainy \& Barokah

Corporate Governance, Environmental Responsibility and Firm Value

\section{Corporate Governance and Corporate Environmental Responsibility}

One agency problem arising in developing countries takes place between majority and minority owners (La Porta et al., 1999). This statement is supported by the research conducted by Tsamenyi et al. (2007) which tests the correlation between ownership structure (block holding) and disclosure made by Ghanaian companies. They find a negative and significant correlation between ownership structure (block holding) and voluntary disclosure made by multinational companies.

In case of non-concentrated (spread) corporate ownership structure, the opportunity a company is owned by the public from various groups gets higher and, consequently, issues related to responsibility to the public gets more important. The higher the importance of public responsibility, the need for involvement in social and environmental activities will be higher, and so be the disclosure of responsibility activity (Ghazali, 2007). The same argument is stated by Tsamenyi et al. (2007), that the more concentrated a company's shareholders, the lower the need for control and supervision is, and on the contrary, more spread corporate ownership structure requires higher supervision by improving corporate reporting transparency (disclosure). Dey (2008) proves that bigger company with more spread ownership, higher debt rate, and risk operation will have a bigger agency problem and, thus, better corporate governance.

Haniffa and Cooke (2002) find a positive correlation between spread ownership and voluntary disclosure with Malaysian companies. The research conducted by Jo and Harjoto $(2011,2012)$ shows that bigger, older companies with better financial performance and more spread ownership structure tend to perform social responsibility. The results of previous research (Chau \& Gray, 2002) also show a positive correlation between a company's spread ownership and social activity disclosure.

$\boldsymbol{H}_{1}$ : Ownership concentration negatively influences corporate environmental responsibility.

According to Herwidayatmo (2000), one of the reasons for weak governance practice in developing countries is auditor's weak supervisory practice. Currently, Indonesia and Malaysia are aware of the importance of internal audit in their governance system. This is proven with the regulation of independent audit committee in corporate governance implementation and conditions to be fulfilled when a company is to go public (Committee, 2000; KNKG, 2006).

Previous research has proven that the audit committee plays a role in the improvement of corporate governance quality (Said, Hj Zainuddin, \& Haron, 2009). McMullen and Raghunandan (1996) and Wright (1996) find that independent audit committee composition is closely related to the company's reporting quality. Audit committee serves an important role in reviewing corporate internal process and control to generate a quality report (Said et al., 2009). This shows that the audit committee composition reflects the quality of the audit as observable in such a corporate report. 
Audit quality is not only observable in the corporate financial statement, but also voluntary corporate activity. Camfferman and Cooke (2002) and Haposoro (2012) prove a positive correlation between audit quality and information disclosure quality. This correlation takes place since more independent audit committee composition may reduce agency problems, which may improve internal control, including in influencing the corporate decision in the performance of environmental responsibility.

\section{$\boldsymbol{H}_{2}$ : Audit quality positively influences corporate environmental responsibility.}

\section{Corporate Governance and Corporate Performance}

According to the agency theory, the agency problem in company arises because of a conflict of interest between shareholders as the principal and manager as the agent. Agency cost then arises as to the result of the need for control and supervision so that the agent will act under the principal's interest. Governance mechanism is a medium to reduce agency cost arising from conflict of interest between stakeholders (Shleifer \& Vishny, 1997). The ownership structure is one corporate governance mechanism which may control agency cost and thus increase firm value (Akbar \& Hindasah, 2007).

Agency conflict may influence firm value. Many types of research of correlation between corporate governance and performance have been conducted (Behbahani et al., 2013; Dey, 2008; Selarka, 2005; Siagian, Siregar, \& Rahadian, 2013). In developing countries, information asymmetry takes places between majority and minority shareholders. This shows that there is a higher agency problem in companies with concentrated ownership structure than companies with spread ownership (Dey, 2008; Ghazali, 2007; Tsamenyi et al., 2007). Spread shareholding may be one mechanism to reduce agency cost in order to increase firm value.

\section{$H_{3}:$ Ownership concentration negatively influences firm value.}

Auditor plays a very important role in influencing the quality of an organization's financial report. Gunawan and Halim (2012) state that information from professional auditor's report will give more certainty and thus give higher reliability to financial statements to be issued. The Indonesian and Malaysian Governments have also obligated all companies registered with their stock exchange to have an audit committee of which some of its members are of the independent audit committee. The Independent audit committee may serve to oversee the agent's performance, observe the internal control system, and test the credibility of accounting information presented by the agent (manager) (Siallagan \& Machfoedz, 2006). All of the functions aim at putting high audit quality in order to increase firm value. The audit committee's supervision and control are conducted in the prevention of manager's moral hazard behavior, which will later influence firm value.

Some researches have proven audit quality's influence, which may be viewed from the existence of an independent audit committee, on firm value. Klein (2002) proves that the independent audit committee influences reported profit quality. Profit quality, as a 
proxy of firm value, is lower with companies which establish independent audit committee compared with those which do not establish it. The same is proven by Siallagan and Machfoedz (2006). Their research also proves that independent audit committee influences firm value by reducing profit management and improve profit quality. McMullen and Raghunandan (1996) in their research state that investors, analysts, and regulators consider that audit committee contributes to increasing firm value through improving financial reporting quality. Bhattacharya (2001) defines a correlation between audit quality and client satisfaction which then influences corporate performance.

\section{$\boldsymbol{H}_{4}$ : Audit quality positively influences firm value.}

\section{Environmental Responsibility and Corporate Performance}

Environmental responsibility activity performed by a company is its responsibility for a social contract with the society in its surrounding environment where it operates. This may be a positive sign the company gives to the society which may later influence its corporate performance. One consideration of whether or not a company will perform environmental responsibility is the activity's implication in the company, whether the benefits to be gained will be comparable to the effort (cost) it has incurred. The impacts of social and environmental responsibility on corporate performance have been tested in some researches.

Generally, firm value is known as an economic measurement reflecting overall business values allocated to the company's shareholders and holders of debt instruments (Malik, 2014). Most of the researches find that companies which perform social and environmental responsibility have better performance (Al-Tuwaijri et al., 2004; Clarkson et al., 2008; Jo \& Harjoto, 2011, 2012; Mishra \& Suar, 2010; Wan Ahamed et al., 2014). A meta-analysis related to such correlation has been conducted by Moser and Martin (2012) and concludes a positive correlation between social and environmental responsibility and corporate performance.

\section{$\boldsymbol{H}_{5}$ : Corporate environmental responsibility positively influences firm value.}

\section{Corporate Governance, Environmental Responsibility and Corporate Performance}

Corporate governance is deemed an effective mechanism to reduce agency problem resulted from conflict of interest between principal and agent (Shleifer \& Vishny, 1997) by disclosing corporate information (Rao et al., 2012) which will influence firm value (Tsamenyi et al., 2007). Jo and Harjoto (2012) test the correlation between corporate governance, social and environmental responsibility, and corporate financial performance. They find that the corporate governance of the previous period (lagged one year) positively influences corporate social and environmental responsibility. They state that corporate social and environmental responsibility activities are the extension of effective governance, which ensures the company's sustainability with accountable and transparent business practice not only shareholders but also for wider community. 
This conforms to the stakeholder theory that a company should use social and environmental responsibility activities as the extension of effective governance mechanism to settle the conflict of interest between manager and stakeholders. An effective governance mechanism should be positively correlated to the corporate decision in performing environmental responsibility activity, and there should be a positive correlation between such environmental responsibility decision and corporate performance since environmental responsibility mitigates conflict of interest between manager and stakeholders (stakeholder theory-based conflict resolution explanation).

Since there is a conflict of interest between manager and stakeholders, social and environmental responsibility serves the role of conflict resolution set between both of them. Based on this correlation, the research result shows a positive correlation between corporate social and environmental responsibility. Their research also confirms the argument that social and environmental responsibility is the extension of effective corporate governance. Gibson and O'Donovan (2007) state that social and environmental responsibility positively influences corporate financial performance and also improves the company's sustainability. An effective governance help company achieve it.

$\boldsymbol{H}_{6}$ : Corporate environmental responsibility mediates the correlation between corporate governance and performance.

\section{Research Method}

\section{Data and Sample}

The data used in this research are obtained from the database of OSIRIS, Bursa Efek Indonesia, and Bursa Malaysia. The researcher conducts a content analysis to obtain environmental responsibility data. The population of this research is all companies registered with $\mathrm{BEI}$ and Bursa Malaysia. The research samples are all mining companies and top 50 manufacturing companies registered with BEI and Bursa Malaysia in 2013. The reason for the selection of mining and manufacturing sectors is that the two are environmentally sensitive industries. The top 50 is used for the manufacturing companies in avoidance of data inequality between both sectors. The research samples are determined by employing a purposive sampling with criteria (1) samples are registered as issuer with BEI and Bursa Malaysia in the period 2013, (2) samples are companies of top 50 market capitalization in manufacturing sector or registered with mining sector, (3) samples present annual report which ends in December 2013.

\section{Variable Measurement}

Corporate governance (CG)

Ownership concentration (OWNCON) is measured from the ratio of shares held by majority shareholder as the total proportion of shares registered with stock exchange 
(Ghazali, 2007). Audit quality (AUDITCOMM) is measured with the number of members of the independent audit committee of a company.

Environmental Responsibility (EI)

The researcher conducts a content analysis related to whether there is environmental responsibility information in the financial statement under GRI G4 guidelines. This research employs a 34 items checklist, the items of which are included in environmental category (EN1 - EN34). Score 1 will be given if the items of information in the guidelines are expressed in financial statement and 0 if otherwise. The environmental responsibility index of each company is calculated by summing up all the values of each company.

$$
E I=\frac{\sum X_{j}}{n_{j}}
$$

$\Sigma X_{j} \quad=$ Total environmental responsibility value of company $\mathrm{j}$

$\mathrm{n}_{\mathrm{j}} \quad=$ Total environmental responsibility value under GRI G4

Firm Value (Q)

Firm value is measured using Tobin's $Q$ value. Tobin's $Q$ measurement follows previous research (Chung \& Pruitt, 1994) and is adapted to Indonesian condition (Darmawati \& Rika, 2005).

$$
\text { Tobin's }^{\prime}=\frac{(M V E+D E B T)}{T A}
$$

MVE = share price $\mathrm{x}$ number of outstanding shares

DEBT = company's total debt

TA $\quad=$ total assets

\section{Control Variables}

This research employs some control variables, which are company size, leverage, the board of directors' structure, and sector. The control variable measurement, company size (SIZE), is measured with market capitalization value, while leverage control variable (LEVERAGE) is measured using a ratio of debt to equity. A dummy variable is employed to measure the control variables of the board of directors structure (Tier) and sector (SECTOR). The dummy variable for the board of directors structure (Tier) is 1 for Malaysian company and 0 for Indonesian company, while for the sector variable (SECTOR) is 1 for a manufacturing company and 0 for a mining company.

\section{Research Model}

According to Gujarati (2009), for a non-biased regression model or BLUE (Best Linear Unbiased Estimator), it is necessary to conduct classical assumption tests as a condition 
of multiple regression analysis tests. The classical assumption tests which have been conducted are residual normality test, heteroscedasticity test, and multicollinearity test. For hypothesis testing, this research employs causal steps (Baron \& Kenny, 1986) by estimating the following three regression equations:

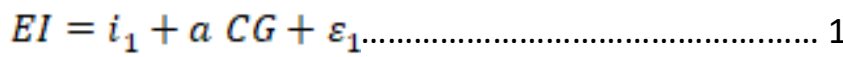

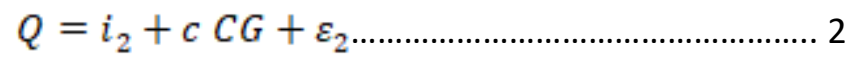

$$
\begin{aligned}
& Q=i_{3}+c^{\prime} C G+b E I+\varepsilon_{3} \ldots \ldots \ldots \ldots \ldots \ldots \ldots \ldots \ldots \ldots \ldots \ldots . . .3
\end{aligned}
$$

Where:

EI = Corporate Environmental Responsibility (Environmental Index)

CG = Corporate Governance

$\mathrm{Q} \quad=$ Firm Value

Some conditions to be met to achieve mediation (Baron \& Kenny, 1986) are:

a) Corporate governance should influence environmental responsibility with equation $(1)(a \neq 0)$.

b) Corporate governance should influence firm value with equation $(2)(c \neq 0)$.

c) Environmental responsibility should influence firm value with equation (3) $(b \neq$ $0)$.

Table 1 Sampling Summary

\begin{tabular}{|c|c|c|c|}
\hline No. & Criteria & Manufacturing & Mining \\
\hline 1 & $\begin{array}{l}\text { Companies registered with } \mathrm{BEI} \text { and } \\
\text { Bursa Malaysia }\end{array}$ & 100 & 58 \\
\hline \multirow[t]{4}{*}{2} & $\begin{array}{l}\text { Companies excluded from the } \\
\text { samples since: }\end{array}$ & & \\
\hline & a. Companies change their sector & (0) & (6) \\
\hline & $\begin{array}{l}\text { b. Companies' financial reporting } \\
\text { period is other than } 31 \\
\text { December }\end{array}$ & (0) & (7) \\
\hline & $\begin{array}{l}\text { c. Companies have incomplete } \\
\text { variable data }\end{array}$ & (0) & (1) \\
\hline 3 & Companies used as final samples & 100 & 44 \\
\hline \multicolumn{2}{|c|}{ Total Final Observations } & \multicolumn{2}{|c|}{144} \\
\hline
\end{tabular}

\section{Result and Discussion}

\section{Variables' Descriptive Statistics}

This research employs 144 samples consisting of 100 manufacturing companies and 44 mining companies. The samples are 64 Malaysian companies and 80 Indonesian companies (See Table 1). The variables' descriptive statistics outline the distribution of the tested variables' data. The summary of the variables' descriptive statistics used in 
this research is presented in Table 2. The results of descriptive statistics show that the samples' average corporate environmental responsibility is low (0.212), with Malaysian companies' environmental responsibility (0.109) is lower than that of Indonesian companies (0.293) and manufacturing companies' average environmental responsibility (0.161) is lower than that of mining companies (0.327). Also, the results of descriptive statistics also show that the sample companies have low firm value and concentrated ownership structure.

Table 2 Variables' Descriptive Statistics

\begin{tabular}{|c|c|c|c|c|c|c|c|}
\hline Variable & Sample & Mean & Median & Maximum & Minimum & Std. Dev. & Obs. \\
\hline \multirow{5}{*}{$\begin{array}{l}\text { Environ- } \\
\text { mental } \\
\text { Respon- } \\
\text { sibility (EI) }\end{array}$} & All & 0.211 & 0.088 & 0.765 & 0.000 & 0.228 & 144 \\
\hline & Tier 1 & 0.109 & 0.059 & 0.765 & 0.000 & 0.166 & 64 \\
\hline & Tier 0 & 0.293 & 0.235 & 0.765 & 0.029 & 0.239 & 80 \\
\hline & Sector 1 & 0.161 & 0.088 & 0.765 & 0.000 & 0.192 & 100 \\
\hline & Sector 0 & 0.327 & 0.338 & 0.765 & 0.000 & 0.261 & 44 \\
\hline Firm & All & 1.827 & 1.167 & 7.769 & 0.339 & 1.711 & 144 \\
\hline \multirow[t]{4}{*}{ Value (Q) } & Tier 1 & 1.615 & 1.069 & 7.769 & 0.406 & 1.576 & 64 \\
\hline & Tier 0 & 1.997 & 1.270 & 7.249 & 0.339 & 1.803 & 80 \\
\hline & Sector 1 & 2.052 & 1.224 & 7.769 & 0.339 & 1.938 & 100 \\
\hline & Sector 0 & 1.317 & 1.017 & 3.613 & 0.429 & 0.836 & 44 \\
\hline Ownership & All & 0.437 & 0.429 & 0.982 & 0.006 & 0.232 & 144 \\
\hline \multirow{4}{*}{$\begin{array}{l}\text { Concen- } \\
\text { tration } \\
\text { (OWNCON) }\end{array}$} & Tier 1 & 0.344 & 0.333 & 0.743 & 0.026 & 0.194 & 64 \\
\hline & Tier 0 & 0.512 & 0.519 & 0.982 & 0.006 & 0.234 & 80 \\
\hline & Sector 1 & 0.442 & 0.443 & 0.982 & 0.006 & 0.24 & 100 \\
\hline & Sector 0 & 0.426 & 0.407 & 0.850 & 0.026 & 0.216 & 44 \\
\hline Audit & All & 1.181 & 1.000 & 2.000 & 0.000 & 0.437 & 144 \\
\hline \multirow{4}{*}{$\begin{array}{l}\text { Com- } \\
\text { mittee } \\
\text { (AUDITCO } \\
\text { MM) }\end{array}$} & Tier 1 & 1.078 & 1.000 & 2.000 & 0.000 & 0.410 & 64 \\
\hline & Tier 0 & 1.263 & 1.000 & 2.000 & 1.000 & 0.443 & 80 \\
\hline & Sector 1 & 1.210 & 1.000 & 2.000 & 1.000 & 0.409 & 100 \\
\hline & Sector 0 & 1.114 & 1.000 & 2.000 & 0.000 & 0.493 & 44 \\
\hline Leverage & All & 0.488 & 0.343 & 2.823 & -3.959 & 0.816 & 144 \\
\hline \multirow[t]{4}{*}{ (LEVERAGE) } & Tier 1 & 0.499 & 0.349 & 2.823 & 0.000 & 0.597 & 64 \\
\hline & Tier 0 & 0.48 & 0.333 & 2.688 & -3.959 & 0.959 & 80 \\
\hline & Sector 1 & 0.46 & 0.334 & 2.823 & -3.959 & 0.735 & 100 \\
\hline & Sector 0 & 0.553 & 0.397 & 2.688 & -3.94 & 0.982 & 44 \\
\hline Company & All & $1,029,481$ & $351,715.5$ & $6,875,270$ & $4,226,852$ & $1,594,807$ & 144 \\
\hline \multirow[t]{4}{*}{ Size (SIZE) } & Tier 1 & $875,238.0$ & $291,817.3$ & $5,830,860$ & $8,288,893$ & $1,421,048$ & 64 \\
\hline & Tier 0 & $1,152,876$ & $408,947.2$ & $6,875,270$ & $4,226,852$ & $1,720,119$ & 80 \\
\hline & Sector 1 & $1,203.323$ & $395,364.0$ & $6,8752,70$ & $111,907.4$ & $1,805,341$ & 100 \\
\hline & Sector 0 & 634,385 & $257,257.4$ & $2,855,967$ & $4,226,852$ & $851,135.9$ & 44 \\
\hline
\end{tabular}

\section{Hypothesis Testing}

The three regression models have fulfilled the classical assumption tests, which are normality, multicollinearity, and heteroscedasticity. The tests employed for normality and heteroscedasticity are Jarque-Bera (JB) and White. The multicollinearity assumption is tested by viewing the tolerance and Variance Inflation Factor (VIF) values. In fulfillment of the assumption, this research conducts a winsorizing of $3 \%$ data of outliers 
and transformation of some variable data, which are an angular transformation for environmental responsibility (EI) variable and natural logarithm transformation for firm value (Q) and company size (SIZE) variable.

Table 3 Results of Regression Analysis on Hypotheses 1 and 2 (Model 1)

\begin{tabular}{|c|c|c|c|c|c|}
\hline Variable & Predicted Sign & Coefficient & Std. Error & t-Statistic & Prob. \\
\hline C & & -0.759 & 0.399 & -1.901 & $0.0594^{*}$ \\
\hline OWNCON & - & 0.403 & 0.187 & 2.160 & $0.0325 * *$ \\
\hline AUDITCOMM & + & 0.336 & 0.094 & 3.593 & $0.0005^{* * *}$ \\
\hline \multicolumn{6}{|l|}{ Control Variable } \\
\hline LEVERAGE & & 0.056 & 0.049 & 1.149 & 0.2527 \\
\hline SIZE & & 0.113 & 0.03 & 3.803 & $0.0002 * * *$ \\
\hline TIER & & -0.332 & 0.089 & -3.750 & $0.0003 * * *$ \\
\hline SECTOR & & -0.472 & 0.092 & -5.118 & $0.0000 * * *$ \\
\hline $\mathrm{N}$ & 144 & & & & \\
\hline R-squared & 0.415 & & & & \\
\hline Adjusted R-squared & 0.389 & & & & \\
\hline F-statistic & 16.199 & & & & \\
\hline Prob(F-statistic) & $0.000 * * *$ & & & & \\
\hline
\end{tabular}

Table 3 presents a summary of the test results of hypotheses 1 and 2 . Hypotheses 1 and 2 aim at testing the correlation between corporate governance and corporate environmental responsibility. The results show that the coefficient of OWNCON variable is positive (0.403) and significant at level $5 \%$. Thus $\mathrm{H}_{1}$ is not supported. It is evident that ownership concentration positively influences environmental responsibility. This result conforms to the argument of Jensen and Meckling (1976) stating that a company with a concentrated ownership structure has lower agency problem since fewer parties own it. The parties have more power and willingness to monitor managers' behavior since they are more bound to the company with their big ownership. It is the control and monitoring which encourage managers to perform environmental responsibility under stakeholders' interest (Chau \& Gray, 2002). Hossain, M. Tan, and Adams, (1994) and Chau and Gray (2002) support the argument through their research which shows a positive correlation between concentrated ownership structure and voluntary information disclosure by Malaysian, Hong Kong, and Singaporean companies.

The coefficient of AUDITCOMM variable is positive (0.336) and significant at level $1 \%$. Thus $\mathrm{H}_{2}$ is supported. It is evident that audit quality positively influences environmental responsibility. Independent audit committee plays an important role in reviewing processes taking place in the company, including the decision of whether or not to perform a voluntary activity like environmental responsibility.

Hypotheses 3 and 4 in this research test the influence of corporate governance on firm value, of which results are presented in Table 4 . The regression output of hypothesis test in Table 4 shows that the coefficient of OWNCON variable is insignificant (0.876). Thus $\mathrm{H}_{3}$ is not supported. Ownership concentration does not influence firm value. 
Demsetz and Villalonga (2001) in their research explain that there is no systematic correlation between ownership structure variance (either concentrated or spread) and firm value variance. In their opinion, a company's ownership structure is the result of a decision which reflects the influence of shareholders and trade in the market. When a private company decides to offer its shares to the public, this means that its shareholders decide to make the ownership structure more spread. On the contrary, in the case of a public company acquisition, its ownership structure change to be more concentrated. That there is no correlation between ownership structure and firm value may also be explained with the argument that, either concentrated or spread, the company's purpose is to maximize shareholders' interest (prosperity), one of which is to increase firm value.

Table 4 Results of Regression Analysis on Hypotheses 3 and 4 (Model 2)

\begin{tabular}{|c|c|c|c|c|c|}
\hline Variable & Predicted Sign & Coefficient & Std. Error & t-Statistic & Prob. \\
\hline $\mathrm{C}$ & & -1.234 & 0.265 & -4.666 & $0.0000^{* * *}$ \\
\hline OWNCON & - & 0.019 & 0.124 & 0.156 & 0.876 \\
\hline AUDITCOMM & + & 0.022 & 0.062 & 0.353 & 0.725 \\
\hline \multicolumn{6}{|l|}{ Control Variable } \\
\hline LEVERAGE & & -0.081 & 0.032 & -2.504 & $0.014 * *$ \\
\hline SIZE & & 0.107 & 0.02 & 5.431 & $0.000 * * *$ \\
\hline TIER & & -0.052 & 0.059 & -0.885 & 0.378 \\
\hline SECTOR & & 0.049 & 0.061 & 0.803 & 0.424 \\
\hline $\mathrm{N}$ & 144 & & & & \\
\hline R-squared & 0.272 & & & & \\
\hline Adjusted R-squared & 0.24 & & & & \\
\hline F-statistic & 8.522 & & & & \\
\hline Prob(F-statistic) & $0.000 *$ & & & & \\
\hline
\end{tabular}

The coefficient of AUDITCOMM variable is insignificant (0.725). Thus $\mathrm{H}_{4}$ is not supported. This research is unable to prove the influence of audit quality on firm value. Audit committee does not reduce the existing agency problem in the company and does not influence firm value. The number of independent audit committee members is not relevant information to society. Thus the market does not respond to such information. Malaysian Code on Corporate Governance and Indonesian General Guideline to Good Corporate Governance have regulated the existence of independent members in the company's audit committee (Committee, 2000; KNKG, 2006). Because of the suggestion, the market does not pay attention to the performance and impacts of the existence of independent members.

Hypothesis 5 tests the influence of corporate environmental responsibility on firm value, while hypothesis 6 aims at proving an indirect correlation between corporate governance and firm value, with the mediation of environmental responsibility. The test results of hypotheses 5 and 6 are presented in Table 5. The regression output of hypothesis test in table 5 shows that the coefficient of El variable is insignificant (0.213). Thus $\mathrm{H}_{5}$ is not supported. Environmental responsibility does not influence firm value. 
The low average value of El variable in this research shows that Malaysian and Indonesian companies' awareness of the importance of environmental responsibility is still low. This conforms to the research conducted by Tsamenyi et al. (2007) that social and environmental responsibility in developing countries is still low. This may also be viewed from the low number of companies in both countries that issue a follow-up report separately from the annual report. Company's decision not to perform environmental responsibility may be caused by investors' tendency not to pay attention to environmental responsibility the companies have conducted when they decide to invest, consequently, the environmental responsibility does not influence the concerned company's firm value. The market does not respond to corporate environmental responsibility, under the research conducted by Gelb and Zarowin (2002) that social and environmental responsibility disclosure does not make share price more informative.

Table 5 Results of Regression Analysis on Hypotheses 5 and 6 (Model 3)

\begin{tabular}{|c|c|c|c|c|c|}
\hline Variable & Predicted Sign & Coefficient & Std. Error & t-Statistic & Prob. \\
\hline $\mathrm{C}$ & & -1.299 & 0.274 & -4.733 & $0.000 * * *$ \\
\hline OWNCON & - & 0.054 & 0.125 & 0.43 & 0.668 \\
\hline AUDITCOMM & + & 0.051 & 0.074 & 0.682 & 0.496 \\
\hline $\mathrm{El}$ & + & -0.085 & 0.068 & -1.252 & 0.213 \\
\hline \multicolumn{6}{|l|}{ Control Variable } \\
\hline LEVERAGE & & -0.076 & 0.034 & -2.225 & 0.028 \\
\hline SIZE & & 0.117 & 0.019 & 6.08 & $0.000 * * *$ \\
\hline TIER & & -0.080 & 0.076 & -1.050 & 0.296 \\
\hline SECTOR & & 0.009 & 0.067 & 0.130 & 0.897 \\
\hline $\mathrm{N}$ & 144 & & & & \\
\hline R-squared & 0.284 & & & & \\
\hline $\begin{array}{l}\text { Adjusted R- } \\
\text { squared }\end{array}$ & 0.247 & & & & \\
\hline F-statistic & 7.702 & & & & \\
\hline Prob(F-statistic) & $0.000 *$ & & & & \\
\hline
\end{tabular}

The mediation correlation in $\mathrm{H}_{6}$ may be tested if the three conditions are fulfilled (Baron \& Kenny, 1986). Non-fulfillment of conditions $b$ and $c$ will result in impractical testing of environmental responsibility as mediation of correlation between corporate governance and firm value. This mediation correlation pattern does not occur in developing countries. Thus $\mathrm{H}_{6}$ is not supported. Environmental responsibility has deemed an extension of effective corporate governance, a medium to solve the existing conflict of interest between manager and stakeholders (Jo \& Harjoto, 2012) which will later influence firm value. This research is unable to prove that environmental responsibility mitigates existing agency problems as presented by Jo and Harjoto (2012). This shows that environmental responsibility does not add information value to reduce conflict of interest.

Market non-responsiveness in developing country to environmental responsibility conducted by a company $\left(\mathrm{H}_{5}\right)$ also confirms that environmental responsibility does not 
have information value in the country since it is deemed not providing information of the company' prospect. That TIER variable is proven not to significantly influence the regression model 3 confirms the argument, showing that Malaysian and Indonesian markets have not considered environmental responsibility as material information in the investment decision. The implication of uninformative environmental responsibility is that firm value is not influenced by such responsibility. This reconfirms that environmental responsibility cannot directly mediate corporate governance and firm value in developing countries.

\section{Conclusion}

This research proves the legitimacy theory and stakeholder theory that a company cannot be separated from a social context and is responsible for fulfilling not only its shareholders' interest but also that of all stakeholders. Environmental responsibility is a realization of effort to fulfill social contract and stakeholders' interest. Market's low response to environmental responsibility proves that environmental responsibility does not directly mediate the correlation between corporate governance and firm value. This research proves that there is not a mediation correlation pattern as proven by Jo and Harjoto (2012) in developing countries. The results of this research are expected to be a reflection for the government and the society in developing countries (particularly Indonesia and Malaysia) in order to be aware of the importance of environmental responsibility. Government's role in each country is very important in its realization.

This research is limited that it only takes 50 big companies of manufacturing sector so that the number of samples from both sectors is not too far. Therefore, it is likely to influence this research' external validity. Consequently, readers are expected to carefully interpret the results of this research. Further research may employ more samples, either with more years of observation or extension of sectors of samples used.

\section{References}

Akbar, M., \& Hindasah, L. (2007). Pengaruh Keputusan Keuangan dan Struktur Kepemilikan terhadap Nilai Perusahaan. Jurnal Akuntansi dan Investasi, 8(2), 167-180. Retrieved from http://journal.umy.ac.id/index.php/ai/article/viewFile/635/790

Al-Tuwaijri, S. A., Christensen, T. E., \& Hughes, K. . (2004). The relations among environmental disclosure, environmental performance, and economic performance: a simultaneous equations approach. Accounting, Organizations and Society, 29(5-6), 447-471. https://doi.org/10.1016/S0361-3682(03)00032-1

Alsaeed, K. (2006). The association between firm-specific characteristics and disclosure: The case of Saudi Arabia. Managerial Auditing Joumal, 21(5), 476-496. https://doi.org/10.1108/02686900610667256

Baron, R. M., \& Kenny, D. a. (1986). The moderator-mediator variable distinction in social psychological research: Conceptual, strategic, and statistical considerations. Joumal of Personality and Social Psychology, 51(6), 1173-1182. https://doi.org/10.1037//0022$\underline{\text { 3514.51.6.1173 }}$ 
Behbahani, S., Zare, R., \& Farzanfar, F. (2013). Examining the effect of auditing quality on nonfinancial information disclosure quality. Interdisciplinary Journal of Contemporary Research In Business, 4(12), 802-810.

Bhattacharya, A. K. (2001). Multiculturalism and the accounting profession : Enhancing employee productivity and client satisfaction. The National Public Accountant, 46(3), 13.

Camfferman, K., \& Cooke, T. E. (2002). An analysis of disclosure in the annual reports of U.K and Dutch Companies. Journal of International Accounting Research, 1(1), 3-30. https://doi.org/10.2308/jiar.2002.1.1.3

Chau, G. K., \& Gray, S. J. (2002). Ownership structure and corporate voluntary disclosure in Hong Kong and Singapore. The International Journal of Accounting, 37(2), 247-265. https://doi.org/10.1016/s0020-7063(02)00153-x

Choi, F. D. S. (2003). International Finance and Accounting Handbook. (Third Edition). New Jersey: John Wiley \& Sons. Retrieved from http://tailieuso.udn.vn/bitstream/TTHL 125/9098/1/InternationalFinanceAndAc countingHandbook.TT.pdf

Chung, K. H., \& Pruitt, S. W. (1994). A simple approximation of Tobin's q. Financial management, 23(3), 70-74. https://doi.org/10.2307/3665623

Clarkson, P. M., Li, Y., Richardson, G. D., \& Vasvari, F. P. (2008). Revisiting the relation between environmental performance and environmental disclosure: An empirical analysis. Accounting, Organizations and Society, 33(4-5), 303-327. https://doi.org/10.1016/j.aos.2007.05.003

Darmawati, K., \& Rika, G. R. (2005). Hubungan Corporate Governance dan Kinerja Perusahaan. Jurnal Riset Akuntansi Indonesia, 70, 135-150.

Deegan, C., \& Rankin, M. (1997). The Materiality of Environmental Information to Users of Annual Reports. Accounting, Auditing \& Accountability Journal, 10(4), 562. https://doi.org/10.1108/09513579710367485

Demsetz, H., \& Villalonga, B. (2001). Ownership structure and corporate performance. Journal of corporate finance, 7(3), 209-233. https://doi.org/10.1016/s0929-1199(01)00020-7

Dey, A. (2008). Corporate Governance and Agency Conflicts. Journal of Accounting Research, 46(5), 1143-1181. https://doi.org/10.1111/j.1475-679X.2008.00301.x

Freeman, R. E., \& Phillips, R. A. (2002). Stakeholder theory: A libertarian defense. Business ethics quarterly, 12(3), 331-349. https://doi.org/10.2307/3858020

Gamerschlag, R., Möller, K., \& Verbeeten, F. (2010). Determinants of voluntary CSR disclosure: empirical evidence from Germany. Review of Managerial Science, 5(2-3), 233-262. https://doi.org/10.1007/s11846-010-0052-3

Gelb, D. S., \& Zarowin, P. (2002). Corporate disclosure policy and the informativeness of stock prices. Review of Accounting Studies, 7(1), 33-52. https://doi.org/10.2139/ssrn.235009

Ghazali, N. A. M. (2007). Ownership structure and corporate social responsibility disclosure: some Malaysian evidence. Corporate Governance, 7(3), 251-266. https://doi.org/10.1108/14720700710756535

Gujarati, D. N. (2009). Basic econometrics. New York: McGraw-Hill Education.

Gunawan, B., \& Halim, M. (2012). Pengaruh Ownership Retention, Reputasi Auditor, Laba Perusahaan, dan Underpricing terhadap Nilai Perusahaan dengan Kepemilikan Manajerial dan Institusional Sebagai Variabel Pemoderasi. Jurnal Akuntansi dan Investasi, 13(2), 99-115. Retrieved from http://journal.umy.ac.id/index.php/ai/article/viewFile/483/619 
Haniffa, R. M., \& Cooke, T. E. (2002). Culture , Corporate Governance and Disclosure in Malaysian Corporations. Abacus, 38(3), 317-349. https://doi.org/10.1111/1467$\underline{6281.00112}$

Haposoro, D. (2012). Pengaruh corporate governance dan kualitas audit terhadap pengungkapan corporate social responsibility. Jurnal Akuntansi \& Manajemen (JAM), 23(3), 199-215.

Haruman, T. (2008). Pengarub Struktur Kepemilikan Terbadap Keputusan Pendanaan Perspektif Agency Theory). A paper was presented in the Accountant Nasional Convention IV, 6-7 September 2000.

Herwidiyatmo. (2000). Peran dan Fungsi Komisaris Independen dan Komite Audit. A paper presented in the National Conference on Management Research 2008, 27 November 2000.

Holder-webb, L., Cohen, J. R., Nath, L., \& Wood, D. (2009). The Supply of Corporate Social Responsibility Disclosures Among U.S. Firms. Journal of Business Ethics, 84(4), 497-527. https://doi.org/10.1007/s10551-008-9721-4

Hossain, M. Tan, L. M., \& Adams, M. (1994). Voluntary Disclosure in an Emerging Capital Market: Some Empirical Evidence from Companies Listed on the Kuala Lumpur Stock Exchange. The International Journal of Accounting: Education and Research, 29, 334 351.

Jensen, M. C., \& Meckling, W. H. (1976). Theory of the Firm : Managerial Behavior , Agency Costs and Ownership Structure. Journal of Financial Economics, 3(4), 305-360. https://doi.org/10.1016/0304-405x(76)90026-x

Jo, H., \& Harjoto, M. a. (2011). Corporate Governance and Firm Value: The Impact of Corporate Social Responsibility. Journal of Business Ethics, 103(3), 351-383. https://doi.org/10.1007/s10551-011-0869-y

Jo, H., \& Harjoto, M. a. (2012). The Causal Effect of Corporate Governance on Corporate Social Responsibility. Journal of Business Ethics, 106(1), 53-72. https://doi.org/10.1007/s10551-011-1052-1

Kaihatu, T. S. (2006). Good corporate governance dan penerapannya di Indonesia. Jurnal Manajemen dan Kewirausahaan, 8(1), 1-9. Retrieved from http://ced.petra.ac.id/index.php/man/article/viewFile/16505/16497

Klein, A. (2002). Audit Committee, Board of Director Characteristics, and Earnings Management. Journal of Accounting and Economics, 33(3), 375-400. https://doi.org/10.1016/s0165-4101(02)00059-9

KNKG. (2006). Pedoman Umum Good Corporate Governance Indonesia.

La Porta, R., Lopez-de-Silanes, F., \& Shleifer, A. (1999). Corporate Ownership Around the World. The Journal of Finance, 54(2), 471-517. https://doi.org/10.1111/0022$\underline{1082.00115}$

Malik, M. (2014). Value-Enhancing Capabilities of CSR: A Brief Review of Contemporary Literature. Journal of Business Ethics, 127(2), 419-438. https://doi.org/10.1007/s10551-014-2051-9

McMullen, D. A., \& Raghunandan, K. (1996). Enhancing audit committee effectiveness. Journal of Accountancy, 182(2), 79. Retrieved from https://search.proquest.com/openview/ba0258b42f302448b1656b39540e51fe/1?p q-origsite $=$ gscholar\&cbl $=41065$

Mishra, S., \& Suar, D. (2010). Does Corporate Social Responsibility Influence Firm Performance of Indian Companies?. Journal of Business Ethics, 95(4), 571-601. https://doi.org/10.1007/s10551-010-0441-1 


\section{Ainy \& Barokah}

Corporate Governance, Environmental Responsibility and Firm Value

Moser, D. V., \& Martin, P. R. (2012). A Broader Perspective on Corporate Social Responsibility Research in Accounting. The Accounting Review, 87(3), 797-806. https://doi.org/10.2308/accr-10257

Rao, K. K., Tilt, C. A., \& Lester, L. H. (2012). Corporate governance and environmental reporting: an Australian study. Corporate Governance: The International Journal of Business in Society, 12(2), 143-163. https://doi.org/10.1108/14720701211214052

Said, R., Hj Zainuddin, Y., \& Haron, H. (2009). The relationship between corporate social responsibility disclosure and corporate governance characteristics in Malaysian public listed companies. Social Responsibility Journal, 5(2), 212-226. https://doi.org/10.1108/17471110910964496

Selarka, E. (2005). Ownership Concentration and firm Value. Emerging Markets, Finance \& Trade, 41(6), 83. https://doi.org/10.1080/1540496x.2005.11052627

Shleifer, A., \& Vishny, R. W. (1997). A Survey of Corporate Governance. The Journal of Finance, 52(2), 737-783. https://doi.org/10.1111/i.1540-6261.1997.tb04820.x

Siagian, F., Siregar, S. V., \& Rahadian, Y. (2013). Corporate governance, reporting quality, and firm value: evidence from Indonesia. Journal of Accounting in Emerging Economies, 3(1), 4-20. https://doi.org/10.1108/20440831311287673

Siallagan, H., \& Machfoedz, M. (2006). Mekanisme Corporate Governance, Kualitas Laba dan Nilai Perusabaan. A Paper was Presented at Simposium Nasional Akuntansi, 9.

Spitzeck, H. (2009). The development of governance structures for corporate responsibility. Corporate Governance: The International Journal of Business in Society, 9(4), 495-505. https://doi.org/10.1108/14720700910985034

Tsamenyi, M., Enninful-Adu, E., \& Onumah, J. (2007). Disclosure and corporate governance in developing countries: evidence from Ghana. Managerial Auditing Journal, 22(3), 319-334. https://doi.org/10.1108/02686900710733170

US SIF Foundation. (2012). Lessons Learned: The Emerging Market Disclosure Project, 2008-2012. Retrieved from https://www.ussif.org/files/Emerging_Markets_F2012.pdf

Wan Ahamed, W. S., Almsafir, M. K., \& Al-Smadi, A. W. (2014). Does Corporate Social Responsibility Lead to Improve in Firm Financial Performance? Evidence from Malaysia. International Journal of Economics and Finance, 6(3), 126-139. https://doi.org/10.5539/ijef.v6n3p126

World Bank Open Data. (2013) Retrieved from http://data.worldbank.org/

Wright, D. W. (1996). Evidence on the relation between corporate governance characteristics and the quality of financial reporting (No. 9601). University of Michigan. 